\title{
ANALISIS SALURAN PEMASARAN BELIMBING DEWA DI KECAMATAN PANCORAN MAS KOTA DEPOK
}

\author{
Fatimah Az Zahra ${ }^{1}$, dan Dahlia Nauly ${ }^{2}$ \\ 1,2)Fakultas Pertanian, Universitas Muhammadiyah Jakarta \\ Jl. K.H. Ahmad Dahlan, Ciputat Timur, Kota Tangerang Selatan, Indonesia \\ e-mail: 1)fatimahzrr@yahoo.com
}

(Diterima 22 September 2020/Revisi 7 Oktober 2020/Disetujui 16 Oktober 2020)

\begin{abstract}
Starfruit is one type of fruit that is widely cultivated in Indonesia, with Depok City occupying the first position in producing star fruit in West Java Province. However, there is a significant difference in price at the farm level and the consumer level which raises the question of how star fruit is marketed in Depok City. The purpose of this study was to determine the pattern of the marketing flow, the marketing function of each marketing agency, the cost of marketing, the farmer's share, and the marketing margin as well as to determine the marketing efficiency of each institution involved in the marketing of star fruit in Pancoran Mas District, Depok City. The method used in this research includes qualitative methods in the form of descriptive analysis for analysis of marketing flow patterns and functions of marketing, and quantitative is useful as an analysis of costs, marketing margins, and marketing efficiency of each marketing channel. Determination of the sample was done purposively with 30 farmers as respondents who were scattered in Rangkap Jaya and Rangkap Jaya Baru Villages, Pancoran Mas District, Depok City. The results of this study indicate; there are five marketing channels. channel I: Farmers - Consumers, channel II: Farmers Retailers (fruit shops) - Consumers, channel III: Farmers - Brokers - Wholesalers - Retailers (traditional markets) - Consumers, channel IV: Farmers - Brokers - Wholesalers - Supplier - Retailer (self-service) Consumers, and line V: Farmers - Suppliers - Retailers (self-service) - Consumers. Each marketing agency performs a different marketing function. The marketing costs and marketing margins that have the highest prices are carried out by channel IV with prices of $R p$ 1,811 and Rp 17,400. Marketing flow I am considered the most efficient when viewed from the farmer's share and marketing margin. The recommended marketing channels for this research are channels II and III if you have a farmer's share of $84 \%$ and $51 \%$. It is recommended that farmers implement a mixed marketing strategy by combining the marketing channels used to increase farmer's share and reduce marketing margins.
\end{abstract}

Keywords: dewa starfruit, marketing channels, marketing efficiency, marketing functions, marketing margins

\begin{abstract}
ABSTRAK
Belimbing adalah salah satu jenis buah yang banyak dibudidayakan di Indonesia, dengan Kota Depok menduduki posisi pertama penghasil belimbing di Provinsi Jawa Barat. Namun, terdapat perbedaan harga yang cukup jauh di tingkat petani dan tingkat konsumen menimbulkan pertanyaan bagaimana pemasaran belimbing di Kota Depok. Tujuan dari penelitian ini dilakukan untuk mengetahui pola alur pemasaran, fungsi pemasaran dari tiap lembaga pemasaran, besar biaya pemasaran, farmer's share, dan marjin pemasaran juga untuk mengetahui seberapa efisiensi pemasaran dari tiap lembaga yang terlibat dalam pemasaran belimbing di Kecamatan Pancoran Mas, Kota Depok. Metode yang digunakan di dalam penelitian ini meliputi metode kualitatif berupa analisis deskriptif untuk analisis pola alur pemasaran dan fungsi dari pemasaran, dan kuantitatif berguna sebagai analisis biaya, marjin pemasaran, dan efisiensi pemasaran dari tiap saluran pemasaran. Penentuan sampel dikerjakan secara purposive dengan 30 petani sebagai responden yang tersebar di Kelurahan Rangkapan Jaya dan Rangkapan Jaya Baru, Kecamatan Pancoran Mas, Kota Depok. Hasil dari penelitian ini menunjukkan; terdapat lima alur pemasaran. alur I: Petani - Konsumen, alur II: Petani - Pedagang Pengecer (toko buah) Konsumen, alur III: Petani - Tengkulak - Pedagang Besar - Pedagang Pengecer (pasar tradisional) - Konsumen, alur IV: Petani - Tengkulak - Pedagang Besar - Supplier - Pedagang Pengecer (swalayan) - Konsumen, dan alur V: Petani - Supplier - Pedagang Pengecer (swalayan) -
\end{abstract}


Konsumen. Setiap lembaga pemasaran mengerjakan fungsi pemasaran yang berbeda. Biaya pemasaran dan marjin pemasaran yang mempunyai harga paling tinggi dilakukan oleh alur IV dengan harga sebesar Rp 1.811,- dan Rp 17.400,-. Alur pemasaran I dirasa paling efisien jika dilihat dari farmer's share dan marjin pemasaran. Saluran pemasaran yang disarankan penelitian ini adalah saluran II dan III jika memiliki farmer's share $84 \%$ dan $51 \%$. Sebaiknya petani melakukan strategi pemasaran campuran dengan mengkombinasi alur pemasaran yang digunakan agar bisa meningkatkan farmer's share dan mengurangi marjin pemasaran.

Kata kunci: belimbing dewa, efisiensi pemasaran, fungsi pemasaran, marjin pemasaran, saluran pemasaran

\section{PENDAHULUAN}

Bertambahnya jumlah penduduk dan meningkatnya kesadaran masyarakat akan pentingnya mengonsumsi makanan berserat menyebabkan komoditas buah-buahan perlu dikembangkan untuk memenuhi kebutuhan gizi harian. World Health Organization (WHO) pada tahun 2003 bersama Food Agriculture Organization (FAO) merekomendasikan konsumsi buah minimal sebesar 400 gram per hari. Kementerian Kesehatan Republik Indonesia juga menganjurkan konsumsi buah setiap hari 3-5 porsi buah sesuai dalam Pedoman Gizi Seimbang.

Salah satu buah yang dibudidayakan di Indonesia adalah belimbing. Jawa Barat merupakan salah satu penghasil buah belimbing di Pulau Jawa setelah Jawa Tengah dengan total produksi tahun 2018 mencapai 10.421 ton (BPS, 2019). Kota Depok menduduki posisi pertama penghasil belimbing di Provinsi Jawa Barat pada tahun 2017, dengan jumlah produksi 30.633 kuintal. Kota Bekasi dan Kota Bogor berada di posisi selanjutnya dengan total produksi 3.978 kuintal dan 1.068 kuintal (BPS, 2018).

Berdasarkan data di atas, Kota Depok merupakan tempat yang potensial untuk mengembangkan usahatani belimbing. Kecamatan Pancoran Mas merupakan sentra utama yang memroduksi belimbing, kelurahan yang terlibat dalam budidaya belimbing Dewa di Kecamatan Pancoran Mas adalah Rangkapan Jaya Baru, Rangkapan Jaya, Mampang, dan Pancoran Mas.

Hasil pengamatan awal sebelum melaksanakan penelitian pada bulan Oktober tahun 2019, diperoleh data bahwa harga belimbing di tingkat konsumen di Kota Depok sebesar Rp 25.000/kg dan di tingkat petani sebesar Rp 8.000/kg. Belimbing yang dijual adalah Grade A dengan karakteristik buah kulit bersih berwarna kuning dengan sedikit hijau pada bagian rusuknya. Perbedaan harga tersebut menimbulkan pertanyaan bagaimana pemasaran belimbing di Kota Depok. Selisih harga diduga disebabkan karena adanya biaya pemasaran yang dikeluarkan oleh masing-masing lembaga pemasaran yang terlibat dalam proses pemasaran belimbing.

Anggraeni et. al., (2018) melakukan penelitian tentang analisis pendapatan dan pemasaran kakao di Kecamatan Bulok Kabupaten Tanggamus. Terdapat delapan saluran pemasaran kakao yang dilakukan oleh petani yang dikategorikan menjadi lima kategori berdasarkan lama penjemuran, yaitu kakao dijemur satu hari, dua hari, tiga hari, empat hari, dan lima hari. Namun, sistem pemasaran kakao masih belum efisien, karena 50\% dari saluran pemasaran yang ada memiliki farmer's share kurang dari $60 \%$, total marjin pemasaran tinggi yaitu sebesar $36,08 \%$ dengan rasio profit margin yang tidak merata.

Nalurita (2008) melakukan penelitian tentang analisis efisiensi pemasaran belimbing Dewa di Kecamatan Pancoran Mas Kota Depok Jawa Barat. Hasil penelitian ini menunjukkan terdapat lima saluran pemasaran, yang melibatkan lembaga pemasaran belimbing Dewa di Kecamatan Pancoran Mas Kota Depok meliputi tengkulak, pedagang besar, pedagang pengecer (toko buah, swalayan, pasar tradisional), supplier, dan Pusat Koperasi Belimbing. Berdasarkan analisis marjin pemasaran saluran pemasaran belimbing 
Dewa yang paling efisien adalah saluran pemasaran empat yaitu meliputi petani pusat koperasi belimbing - pedagang Pengecer (toko buah) - konsumen, karena memiliki total marjin pemasaran terkecil sebesar Rp 5.000/kg.

Penelitian ini dengan penelitian Nalurita (2008) memiliki perbedaan rentang waktu yang berjarak lebih dari 10 tahun, sehingga diharapkan pada penelitian ini dapat menjawab masalah pemasaran belimbing Dewa yang relevan di masa sekarang. Penelitian di atas juga mengindikasikan bahwa panjang pendek dan banyaknya saluran pemasaran merupakan faktor penentu efisien atau tidaknya suatu pemasaran yang dilakukan dan dapat disimpulkan bahwa semakin pendek saluran pemasaran pemasaran suatu produk, dengan marjin pemasaran rendah, serta farmer's share yang tinggi, maka pemasaran akan makin efisien. Namun, saluran pemasaran yang sedikit juga tidak menjamin efisiennya suatu pemasaran. Hasil penelitian tersebut di atas dijadikan acuan bagi peneliti untuk menganalisis pemasaran belimbing Dewa di Kecamatan Pancoran Mas Kota Depok.

Tujuan dari penelitian ini adalah menganalisis pola saluran pemasaran, fungsi pemasaran, farmer share dan efisiensi dari masing-masing saluran pemasaran belimbing Dewa di Kota Depok.

\section{METODE}

\section{PENGUMPULAN DATA}

Penelitian dilakukan di Kota Depok pada bulan November 2019 sampai Januari 2020. Kecamatan Pancoran Mas dijadikan sebagai daerah penelitian dengan pertimbangan bahwa daerah tersebut merupakan sentra utama yang memproduksi belimbing dalam jumlah besar dengan luas areal yang diusahakan untuk tanaman belimbing Dewa seluas 31,22 ha dengan jumlah populasi 8.649 pohon (Dinas Ketahanan Pangan, Pertanian, dan Perikanan Kota Depok, 2019).
Wilayah yang digunakan dalam pemilihan sampel dipilih secara sengaja (purposive sampling) yaitu kelurahan di Kecamatan Pancoran Mas yang memiliki populasi pohon belimbing paling banyak. Kelurahan yang dipilih adalah Rangkapan Jaya Baru dan Rangkapan Jaya. Singarimbun dan Effendi (1995) mengemukakan bahwa jumlah sampel yang dianalisis harus mengikuti distribusi normal, dimana sampel yang tergolong mengikuti distribusi normal adalah sampel yang jumlahnya lebih besar atau sama dengan 30 responden.

Tugas dan fungsi lembaga-lembaga pemasaran buah belimbing Dewa di Kota Depok diperoleh dengan metode snowball sampling yaitu menelusuri lembaga atau pedagang responden yang memasarkan buah belimbing Dewa di Kecamatan Pancoran Mas mulai dari petani sampai konsumen akhir yang berupa informasi dari produsen dan pedagang.

\section{METODE ANALISIS}

Metode analisis yang digunakan dalam penelitian ini adalah sebagai berikut:

\section{Analisis Deskriptif}

Saluran pemasaran dan fungsi lembaga pemasaran buah belimbing Dewa yang ada di Kecamatan Pancoran Mas dianalisis dengan menggunakan metode analisis deskriptif yaitu metode yang berfungsi untuk mendeskripsikan atau memberi gambaran terhadap objek yang diteliti melalui data atau sampel yang telah terkumpul sebagaimana adanya (Sugiyono, 2013).

\section{Analisis Fungsi Pemasaran}

Analisis fungsi pemasaran dilakukan untuk mengetahui fungsi-fungsi pemasaran yang dilakukan tiap lembaga pemasaran dalam proses penyaluran belimbing dewa di Kota Depok. Lembaga pemasaran berperan sebagai perantara penyampaian barang dari titik produsen ke titik konsumen seperti fungsi pertukaran, fungsi fisik, dan fungsi fasilitas, sehingga membentuk saluran pemasaran (Din dan Badar, 2011). 


\section{Analisis Biaya Pemasaran}

Sudiyono (2002) menyatakan bahwa biaya pemasaran dan marjin pemasaran di tingkat lembaga dalam saluran pemasaran dianalisis dengan menghitung besarnya biaya dan keuntungan pada tiap lembaga perantara pada berbagai saluran pemasaran.

a. Biaya pemasaran

Biaya pemasaran adalah biaya yang dikeluarkan untuk memasarkan suatu komoditi dari produsen ke konsumen. Biaya pemasaran dapat dihitung dengan menggunakan rumus sebagai berikut:

$$
B p=B p_{1}+B p_{2}+B p_{3}+\cdots+B p_{n}
$$

Keterangan:

$B p=$ biaya pemasaran buah belimbing Dewa $(\mathrm{Rp} / \mathrm{Kg})$,

$B p_{n}$ = biaya pemasaran tiap lembaga pemasaran buah belimbing Dewa $(\mathrm{Rp} / \mathrm{Kg})$,

$n=$ jumlah lembaga pemasaran buah belimbing Dewa.

b. Keuntungan pemasaran

Keuntungan pemasaran adalah penjumlahan dari keuntungan yang diterima oleh setiap lembaga pemasaran. Keuntungan pemasaran dapat dihitung dengan menggunakan rumus sebagai berikut:

$$
K p=K p_{1}+K p_{2}+K p_{3}+\cdots+K p_{n}
$$

Keterangan:

$K p=$ keuntungan pemasaran buah belimbing Dewa $(\mathrm{Rp} / \mathrm{Kg})$

$K p_{n}=$ keuntungan tiap-tiap lembaga pemasaran buah belimbing Dewa $(\mathrm{Rp} / \mathrm{Kg})$

\section{Analisis Marjin Pemasaran}

Marjin pemasaran merupakan perbedaan harga yang diterima oleh petani dengan harga yang dibayarkan oleh konsumen (Sudiyono, 2002). Untuk menganalisis marjin pemasaran dalam penelitian ini, data harga yang digunakan adalah harga di tingkat petani dan harga di tingkat lembaga pemasaran, sehingga dalam perhitungan marjin pemasaran digunakan rumus:

$$
\begin{gathered}
M m p=P r-P f \\
M m p l=P s-P b
\end{gathered}
$$

Keterangan:

$M m p=$ marjin pemasaran di tingkat petani

$\mathrm{Mmpl}=$ marjin pemasaran di tingkat lembaga pemasaran

$\mathrm{Pr} \quad=$ harga di tingkat kelembagaan pemasaran tujuan pemasaran petani

Pf = harga di tingkat petani

$P S \quad=$ harga jual pada setiap tingkat lembaga pemasaran

$\mathrm{Pb}=$ harga beli pada setiap tingkat lembaga pemasaran

\section{Analisis Farmer's Share}

Pengukuran efisiensi ekonomis sering menggunakan marjin pemasaran sebagai alat ukurnya. Efisiensi dari suatu sistem pemasaran dapat diketahui dengan menganalisa marjin pemasaran dan memperhitungkan bagian yang diterima oleh petani (farmer's share) (Sudiyono, 2002). Bagian yang diterima petani (farmer's share) dapat dihitung menggunakan rumus:

$$
F=\left\{1-\frac{M p}{\operatorname{Pr}}\right\} \times 100
$$

Keterangan:

$F=$ bagian yang diterima petani belimbing Dewa $(\%)$

$M p=$ marjiin pemasaran $(\mathrm{Rp} / \mathrm{kg})$

$\operatorname{Pr}=$ harga belimbing Dewa di tingkat konsumen $(\mathrm{Rp} / \mathrm{kg})$

Suatu usaha secara normal dikatakan bisa dilanjutkan apabila tidak mengalami kerugian atau usaha tersebut mengalami impas. Bila bagian yang diterima petani $<50 \%$ berarti belum efisien, dan bila bagian yang diterima petani > 50\% maka pemasaran dikatakan efisien (Sudiyono, 2002). 


\section{HASIL DAN PEMBAHASAN}

\section{ANALISIS SALURAN PEMASARAN}

Sistem pemasaran belimbing Dewa melibatkan beberapa pelaku pemasaran yaitu (1) petani, (2) pedagang pengumpul (tengkulak/ penebas), (3) supplier pasar modern, (4) pedagang besar, (5) pedagang pengecer (toko buah), (6) pedagang pengecer (pasar tradisional), dan (7) pedagang pengecer (pasar modern/swalayan). Saluran pemasaran belimbing Dewa dapat dilihat pada Gambar 1 .

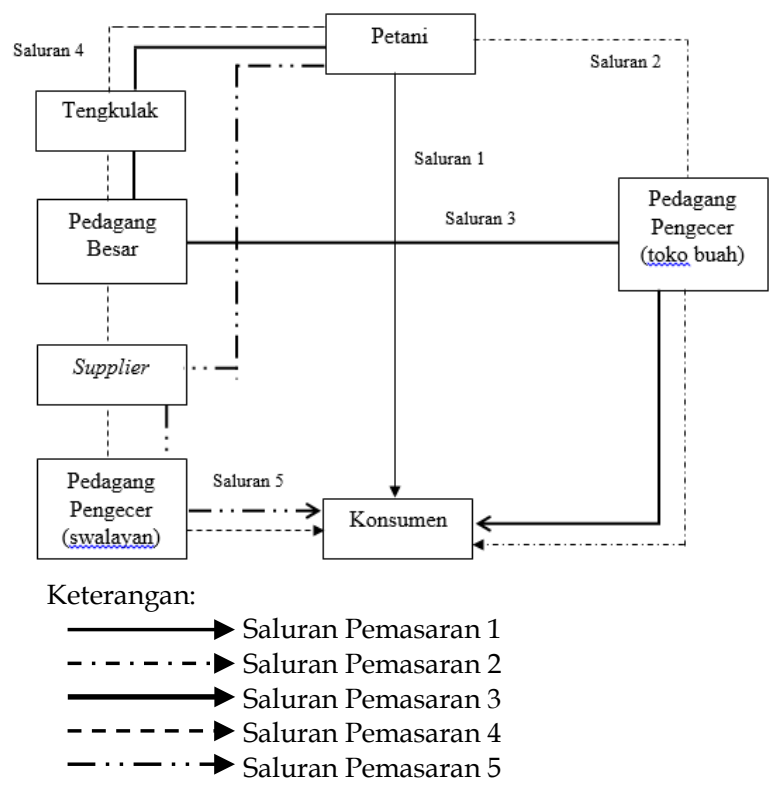

\section{Gambar 1. Saluran Pemasaran Belimbing Dewa di Kota Depok}

Pengamatan di lokasi penelitian menunjukkan bahwa terdapat lima saluran pemasaran. Sebagian besar petani menjual hasil panennya kepada tengkulak dan ada sebagian kecil yang menjual langsung ke konsumen. Satu petani bisa menggunakan lebih dari satu saluran pemasaran, biasa disebut dengan mixed marketing strategy atau strategi pemasaran campuran. Kim et.al., (2014) mengemukakan bahwa $40 \%$ pemasaran yang dilakukan langsung oleh petani dan 60\% dilakukan dengan perantara akan jadi pilihan terbaik (bagi mereka yang mempertimbangkan) untuk mengurangi resiko produsen berdasarkan rerata dan ragam keuntungan.
Penelitian ini memiliki kesamaan dengan hasil penelitian Nalurita (2008) yaitu terdapat lima saluran pemasaran. Namun, tiap saluran pemasaran memiliki kelembagaan yang berbeda. Nalurita (2008) tidak menemukan adanya petani yang menjual langsung belimbing ke konsumen sedangkan dalam penelitian ini, sebanyak $16,66 \%$ atau lima orang petani responden langsung menjual belimbing Dewa ke konsumen. Sebagian besar petani pada saat itu menjual ke tengkulak dan sebagian kecil ke pusat koperasi belimbing. Sedangkan dalam penelitian ini, petani lebih ragam dalam menjual hasil panennya yaitu dapat langsung ke konsumen, tengkulak, pedagang pengecer, bahkan supplier. Pusat koperasi tak lagi jadi pilihan petani dalam menjual belimbingnya karena koperasi telah tutup. Ragamnya petani dalam menjual pada pembeli pertama, mengindikasikan saat ini telah adanya kekuatan petani di Kecamatan Pancoran Mas dalam memilih mitra penjualan belimbing.

\section{ANALISIS FUNGSI PEMASARAN}

Saluran I, petani melakukan fungsi pertukaran berupa pejualan, fungsi fisik yang dilakukan yaitu pengangkutan dan pengemasan, dan fungsi fasilitas yang dilakukan yaitu pembiayaan dan informasi pasar. Saluran II, petani melakukan fungsi pertukaran berupa pejualan, fungsi fisik yang dilakukan yaitu pengangkutan dan pengemasan, dan fungsi fasilitas yang dilakukan yaitu penanggungan resiko, pembiayaan dan informasi pasar. Pedagang pengecer (toko buah) melakukan semua fungsi pemasaran yaitu pertukaran, fisik, dan fasilitas.

Saluran III, petani hanya melakukan fungsi pertukaran berupa penjualan dan fungsi fasilitas. Pedagang pengumpul tidak melakukan fungsi pengemasan dan penyimpanan. Pedagang besar tidak melakukan fungsi penyimpanan. Pedagang pengecer (pasar tradisional) melakukan semua fungsi pemasaran.

Saluran IV, petani tidak melakukan fungsi pembelian dan fungsi fisik. Pedagang pengumpul dan pedagang besar tidak melaku- 
kan fungsi penyimpanan. Supplier melakukan semua fungsi pertukaran, fungsi pengangkutan, penanggungan resiko, pembiayaan, dan informasi pasar. Pedagang pengecer (swalayan) melakukan semua kegiata fungsi pemasaran.

Saluran $\mathrm{V}$, petani tidak melakukan fungsi pembelian, penyimpanan, dan penanggungan resiko. Supplier tidak melakukan fungsi pengemasan, penyimpanan, dan sortasi. Pedagang pengecer (swalayan) tidak melakukan fungsi penanggungan resiko.

Terdapat sedikit perbedaan fungsi-fungsi pemasaran yang dilakukan lembaga pemasaran dalam penelitian Nalurita (2008) dan penelitian ini. Penelitian Nalurita (2008), fungsi fisik yang dilakukan petani secara umum tidak melakukan fungsi pengangkutan, dalam penelitian ini petani yang menjual langsung ke konsumen, bermitra dengan pedagang pengecer dan supplier melakukan fungsi pengangkutan. Petani tidak melakukan fungsi penanggungan resiko karena resiko ditanggung oleh pedagang pengumpul/tengkulak (Nalurita, 2008). Sedangkan dalam penelitian ini, petani harus menanggung resiko karena fluktuasi harga belimbing Dewa di pasaran, jika tengah panen raya harga belimbing akan mengalami penurunan. Petani juga telah memahami tentang informasi pasar, kondisi ini sangat berbeda dengan keadaan kurang lebih sepuluh tahun lalu, dalam penelitian Narulita (2008), petani mendapat informasi pasar dari tengkulak, rekan sesama petani, juga pusat koperasi belimbing.

\section{ANALISIS MARJIN PEMASARAN}

Proses mengalirnya barang dari produsen ke konsumen memerlukan biaya, semakin panjang saluran pemasaran maka akan semakin besar pula biaya yang dikeluarkan dalam pemasarannya. Biaya, keuntungan, dan marjin pemasaran saluran I dapat dilihat pada Tabel 1.
Tabel 1. Biaya, Keuntungan, dan Marjin Pemasaran Saluran Pemasaran I

\begin{tabular}{|c|c|c|c|}
\hline No. & Uraian & $\mathrm{Rp} / \mathrm{Kg}$ & $\begin{array}{c}\text { Pangsa } \\
(\%)\end{array}$ \\
\hline \multirow[t]{5}{*}{1.} & Petani & & \\
\hline & $\begin{array}{l}\text { a. Harga di tingkat petani } \\
\text { b. Biaya pemasaran }\end{array}$ & 15.710 & 100 \\
\hline & 1) Plastik & 110 & 0,70 \\
\hline & Jumlah biaya & 110 & 0,70 \\
\hline & $\begin{array}{l}\text { c. Harga yang diterima } \\
\text { petani }\end{array}$ & 15.710 & 100 \\
\hline \multirow[t]{2}{*}{2.} & Konsumen & & \\
\hline & Harga beli & 15.710 & 100 \\
\hline \multicolumn{2}{|c|}{ Marjin Pemasaran } & 15.600 & 99,29 \\
\hline
\end{tabular}

Saluran pemasaran I merupakan petani yang menjual langsung ke konsumen dengan harga rata-rata $\mathrm{Rp} 15.710,-/ \mathrm{kg}$. Saluran ini memiliki marjin sebesar Rp 15.600,- atau 99,29\%. Petani sekaligus menjadi lembaga pemasaran belimbing Dewa mendapatkan tambahan keuntungan atau marjin yang tinggi dari rata-rata harga di tingkat petani sebesar Rp 15.700,-/kg. Namun, petani harus mengeluarkan biaya pemasaran sebesar $\mathrm{Rp}$ $110,-/ \mathrm{kg}$ untuk plastik pembungkus belimbing sehingga harga jual ke konsumen sebesar Rp 15.710,-/kg dan menerima resiko jika belimbing tidak habis terjual lebih dari empat hari. Tabel 2 menunjukkan biaya, keuntungan, dan marjin pemasaran untuk saluran II.

Saluran pemasaran II merupakan petani yang mampu menjual langsung ke pedagang pengecer baik pasar tradisional maupun toko buah. Petani mengeluarkan biaya pemasaran sebesar $\mathrm{Rp} 1.500,-/ \mathrm{kg}$ untuk melakukan pemanenan, biaya ini sudah termasuk biaya petik dan biaya angkut. Petani dan pedagang pengecer bertemu di pasar untuk melakukan transaksinya. Pedagang pengecer membeli belimbing seharga $\mathrm{Rp} 12.500,-/ \mathrm{kg}$ dan dijual lagi ke konsumen dengan harga $\mathrm{Rp} 15.000$,$/ \mathrm{kg}$. Pedagang pengecer mengeluarkan biaya pengangkutan $\mathrm{Rp} 140,-/ \mathrm{kg}$ dan biaya pengemasan Rp 170,-/kg. Pengangkutan dilakukan dari mobil pick up ke kios tempat berdagang, sedangkan pengemasan menggunakan plastik kiloan untuk mengemas belimbing. Biaya penyusutan belimbing yang dikeluarkan sebesar $\mathrm{Rp}$ 53,-/kg. Pedagang pengecer mendapat keuntungan sebesar Rp 2.137,-/kg 
dengan marjin pemasaran dari petani ke konsumen sebesar Rp 2.500,-/ kg.

Tabel 2. Biaya, Keuntungan, dan Marjin Pemasaran Saluran Pemasaran II

\begin{tabular}{|c|c|c|c|}
\hline No. & Uraian & $\mathbf{R p} / \mathbf{K g}$ & $\begin{array}{c}\text { Pangsa } \\
(\%)\end{array}$ \\
\hline \multirow[t]{5}{*}{1.} & Petani & & \\
\hline & $\begin{array}{l}\text { a. Harga di tingkat petani } \\
\text { b. Biava pemasaran }\end{array}$ & 12.500 & 83,33 \\
\hline & 1) biaya panen & 1.500 & 10 \\
\hline & Jumlah biaya & 1.500 & 10 \\
\hline & $\begin{array}{l}\text { c. Harga yang diterima } \\
\text { petani }\end{array}$ & 12.500 & 83,33 \\
\hline \multirow[t]{10}{*}{2.} & $\begin{array}{l}\text { Pedagang pengecer (toko } \\
\text { buah) }\end{array}$ & & \\
\hline & a. Harga beli & 12.500 & 83,33 \\
\hline & b. Biaya pemasaran & & \\
\hline & 1) pengangkutan & 140 & 0,93 \\
\hline & 2) pengemasan & 170 & 1,13 \\
\hline & 3) penyusutan & 53 & 0,35 \\
\hline & Jumlah biaya & 363 & 2,42 \\
\hline & c. Keuntungan & 2.137 & 14,25 \\
\hline & d. Marjin & 2.500 & 16,67 \\
\hline & e. Harga jual & 15.000 & 100 \\
\hline \multirow[t]{2}{*}{3.} & Konsumen & & \\
\hline & Harga beli & 15.000 & 100 \\
\hline \multicolumn{2}{|c|}{ Total Biaya Pemasaran } & 363 & 2,42 \\
\hline \multicolumn{2}{|c|}{ Total Keuntungan } & 2.137 & 14,25 \\
\hline \multicolumn{2}{|c|}{ Total Marjin Pemasaran } & 2.500 & 16,60 \\
\hline
\end{tabular}

Berdasarkan Tabel 3 menunjukkan bahwa saluran pemasaran III belimbing Dewa meliputi petani, tengkulak, pedagang besar, dan pedagang pengecer. Total biaya pemasaran pada saluran pemasaran III sebesar Rp 1.703,-/ kg dengan keuntungan pemasaran total sebesar Rp 5.697,-/ kg. Besarnya biaya dan keuntungan tergantung dari banyaknya lembaga pemasaran yang terlibat dalam saluran pemasaran. Total marjin pemasaran saluran ini sebesar Rp 7.400,-/ kg. Besarnya nilai marjin ini disebabkan karena tengkulak membeli belimbing langsung dari petani dengan harga yang rendah.

Pembiayaan yang dikeluarkan tengkulak dan pedagang besar pada Tabel 4 tidak berbeda jauh dengan saluran pemasaran III pada Tabel 3. Total biaya pemasaran saluran pemasaran IV sebesar $\mathrm{Rp} 1.811,-/ \mathrm{kg}$, total marjin pemasaran sebesar Rp $17.400,-/ \mathrm{kg}$, dan total keuntungan sebesar Rp 15.449,-/ kg.
Saluran pemasaran ini memiliki marjin pemasaran yang lebih tinggi daripada saluran I, II, dan III. Hal ini disebabkan karena banyak lembaga pemasaran yang terlibat dan mengakibatkan harga di tingkat konsumen lebih mahal.

Tabel 3. Biaya, Keuntungan, dan Marjin Pemasaran Saluran Pemasaran III

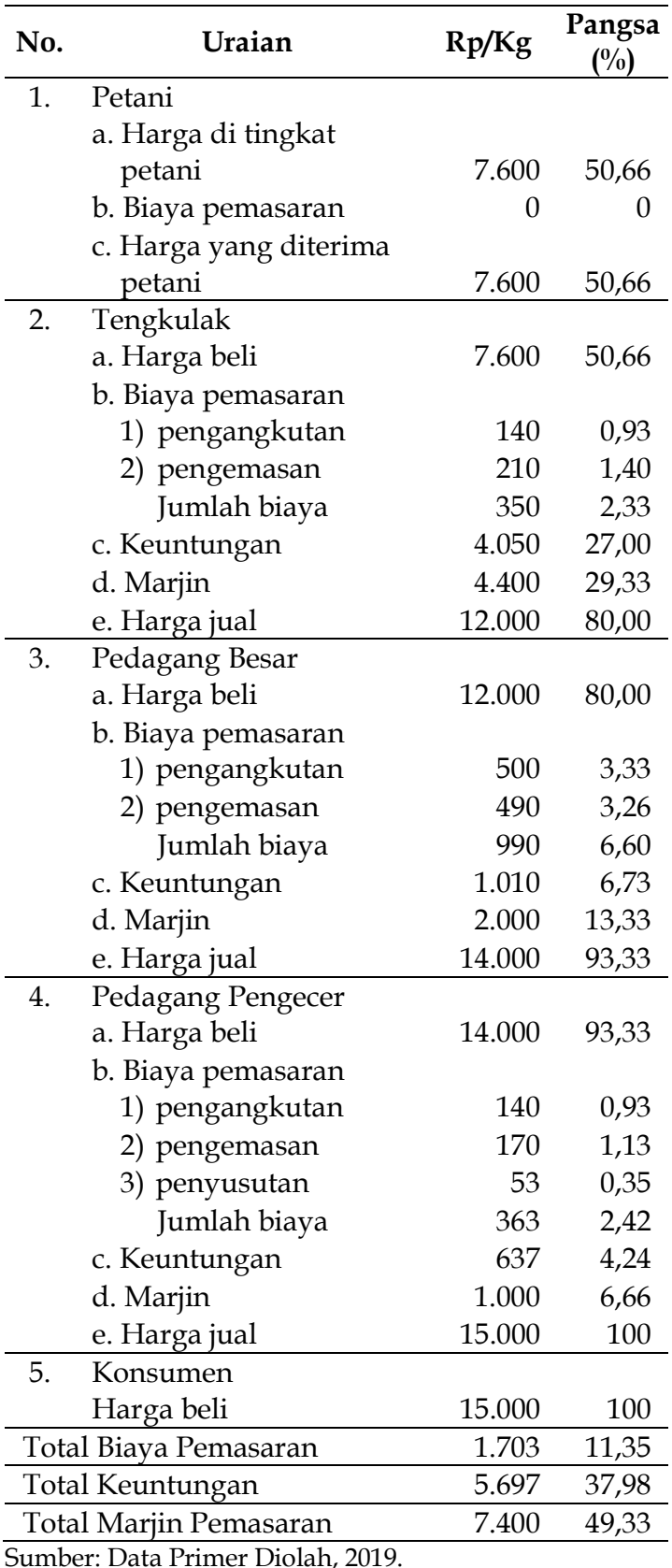


Tabel 4. Biaya, Keuntungan, dan Marjin Pemasaran Saluran Pemasaran IV

\begin{tabular}{|c|c|c|c|}
\hline No. & Uraian & $\mathrm{Rp} / \mathrm{Kg}$ & $\begin{array}{c}\text { Pangsa } \\
(\%)\end{array}$ \\
\hline \multirow[t]{4}{*}{1.} & Petani & & \\
\hline & a. Harga di tingkat petani & 7.600 & 30,40 \\
\hline & b. Biaya pemasaran & 0 & 0 \\
\hline & $\begin{array}{l}\text { c. Harga yang diterima } \\
\text { petani }\end{array}$ & 7.600 & 30,40 \\
\hline \multirow{9}{*}{2.} & Tengkulak & & 30,40 \\
\hline & a. Harga beli & 7.600 & 30,40 \\
\hline & b. Biaya pemasaran & & \\
\hline & 1) pengangkutan & 140 & 0,56 \\
\hline & 2) pengemasan & 210 & 0,84 \\
\hline & Jumlah biaya & 350 & 1,40 \\
\hline & c. Keuntungan & 4.050 & 16,20 \\
\hline & d. Marjin & 4.400 & 17,60 \\
\hline & e. Harga jual & 12.000 & 48,00 \\
\hline \multirow[t]{10}{*}{3.} & Pedagang Besar & & \\
\hline & a. Harga beli & 12.000 & 48,00 \\
\hline & b. Biaya pemasaran & & \\
\hline & 1) pengangkutan & 500 & 2,00 \\
\hline & 2) pengemasan & 490 & 1,96 \\
\hline & 3) penyusutan & 53 & 0,21 \\
\hline & Jumlah biaya & 1.043 & 4,17 \\
\hline & c. Keuntungan & 3.957 & 15,82 \\
\hline & d. Marjin & 5.000 & 20 \\
\hline & e. Harga jual & 17.000 & 68 \\
\hline \multirow[t]{9}{*}{4.} & Supplier & & \\
\hline & a. Harga beli & 17.000 & 68 \\
\hline & b. Biaya pemasaran & & \\
\hline & 1) pengangkutan & 140 & 0,56 \\
\hline & 2) pengemasan & 170 & 0,68 \\
\hline & Jumlah biaya & 310 & 1,24 \\
\hline & c. Keuntungan & 4.690 & 18,76 \\
\hline & d. Marjin & 5.000 & 20,00 \\
\hline & e. Harga jual & 22.000 & 88,00 \\
\hline
\end{tabular}

\begin{tabular}{lrr}
\hline 5. $\begin{array}{l}\text { Pedagang Pengecer } \\
\text { (swalayan) }\end{array}$ & & \\
a. Harga beli & 22.000 & 88,00 \\
b. Biaya pemasaran & & \\
$\quad$ 1) pengemasan & 248 & 0,99 \\
$\quad$ Jumlah biaya & 248 & 0,99 \\
& 2.752 & 11,00 \\
c. Keuntungan & 3.000 & 12 \\
d. Marjin & 25.000 & 100 \\
$\quad$ e. Harga jual & & \\
\hline K. Konsumen & 25.000 & 100 \\
$\quad$ Harga beli & 1.811 & 7,24 \\
\hline Total Biaya Pemasaran & 15.449 & 61,79 \\
\hline Total Keuntungan & 17.400 & 69,60 \\
\hline Total Marjin Pemasaran & & \\
\hline Sumber: Data Primer Diolah, 2019. &
\end{tabular}

Total marjin pemasaran pada saluran pemasaran V sebesar Rp 13.289,-/ kg dengan marjin tertinggi terdapat pada lembaga pemasaran pedagang pengecer swalayan. Total biaya pemasaran yang dikeluarkan tiap lembaga pemasaran sebesar Rp 441,-/kg dan total keuntungan yang diperoleh dalam saluran pemasaran ini adalah sebesar Rp 12.988,/kg. Biaya, keuntungan, dan marjin pemasaran saluran $\mathrm{V}$ dapat dilihat pada Tabel 5 .

Tabel 5. Biaya, Keuntungan, dan Marjin Pemasaran Saluran Pemasaran V

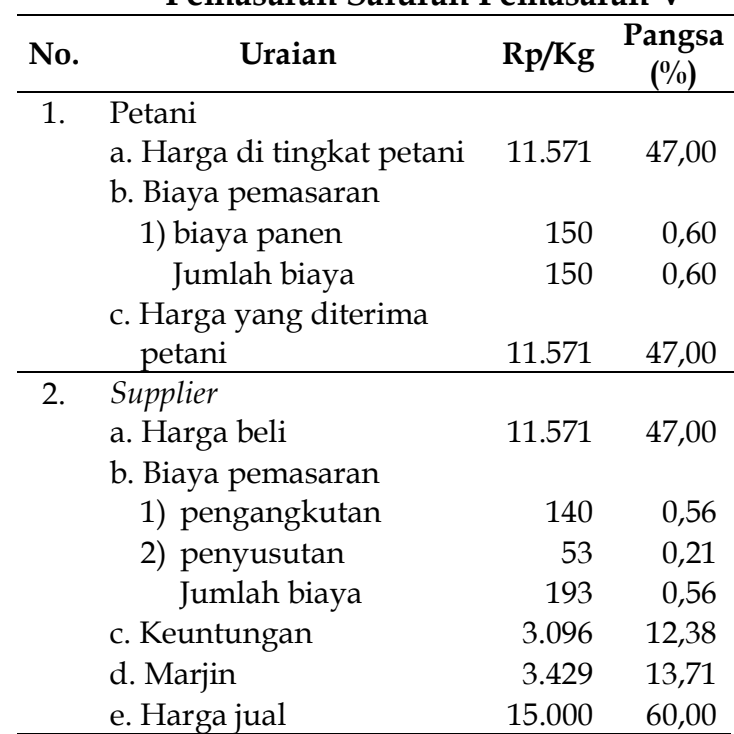

3. Pedagang Pengecer (swalayan)

\begin{tabular}{lrr} 
a. Harga beli & 15.000 & 60,00 \\
b. Biaya pemasaran & 248 & 1,03 \\
c. Keuntungan & 9.752 & 39,01 \\
d. Marjin & 10.000 & 40,00 \\
e. Harga jual & 25.000 & 100 \\
\hline
\end{tabular}

4. Konsumen

\begin{tabular}{lrr}
\multicolumn{1}{c}{ Harga beli } & 25.000 & 100 \\
\hline Total Biaya Pemasaran & 441 & 1,76 \\
\hline Total Keuntungan & 12.988 & 51,95 \\
\hline Total Marjin Pemasaran & 13.289 & 53,16 \\
\hline
\end{tabular}

Sumber: Data Primer Diolah, 2019.

\section{ANALISIS FARMER'S SHARE}

Dinilai dari total marjin pemasaran dan farmer's share maka saluran pertama merupakan saluran pemasaran yang paling efisien $100 \%$, begitu juga saluran dua dan tiga berurutan sebesar $84 \%$ dan $51 \%$. Saluran pemasaran pertama yaitu $100 \%$, artinya produsen atau petani menerima $100 \%$ dari harga yang dibayarkan konsumen. Hal ini sesuai dengan pendapat Sudiyono (2002), bila bagian yang diterima petani $<50 \%$ berarti belum efisien, dan bila bagian yang diterima petani $>50 \%$ maka pemasaran dikatakan efisien. Saluran empat sebesar 31\% dan lima sebesar $46 \%$ tidak efisien karena banyaknya 
lembaga pemasaran yang terlibat dalam saluran tersebut, sehingga harga jual ditingkat petani menjadi rendah yaitu sebesar $\mathrm{Rp}$ 7.600,-/kg dan Rp 11.571,-/kg. Supplier pada saluran kelima mengambil keuntungan yang cukup besar yaitu Rp 9.752,-/ kg atau 39,01\% karena dalam saluran ini supplier yang paling tahu tentang informasi pasar baik di tingkat petani maupun pedagang pengecer swalayan.

\begin{tabular}{|c|c|c|c|}
\hline Tabel 6. & $\begin{array}{l}\text { alisis } \\
\text { uran } \\
\text { wa }\end{array}$ & $\begin{array}{l}\text { rmer's } S h \\
\text { masaran }\end{array}$ & $\begin{array}{l}\text { are pada } \\
\text { Belimbing }\end{array}$ \\
\hline $\begin{array}{l}\text { Saluran } \\
\text { Pemasaran }\end{array}$ & $\begin{array}{c}\text { Harga di } \\
\text { Tingkat } \\
\text { Petani } \\
\text { (Rp/Kg) }\end{array}$ & $\begin{array}{c}\text { Harga di } \\
\text { Tingkat } \\
\text { Konsumen } \\
\text { (Rp/Kg) }\end{array}$ & $\begin{array}{l}\text { Farmer's } \\
\text { Share }(\%)\end{array}$ \\
\hline I & 15.710 & 15.710 & 100 \\
\hline II & 12.500 & 15.000 & 84 \\
\hline III & 7.600 & 15.000 & 51 \\
\hline IV & 7.600 & 25.000 & 31 \\
\hline V & 11.571 & 25.000 & 46 \\
\hline
\end{tabular}

Terdapat dua farmer's share yang efisien dalam penelitian Nalurita (2008) yaitu pada saluran IV sebesar 56,52\% dengan lembaga pemasaran yang terlibat meliputi petani pusat koperasi - pedagang pengecer konsumen, sedangkan saluran pemasaran terpendek dalam penelitian tersebut terdapat pada saluran III dengan lembaga pemasaran petani - pedagang pengecer - konsumen dengan farmer's share sebesar 54,55\% yang dapat mensubstitusi saluran pemasaran IV. Dalam penelitian ini, terdapat tiga farmer's share yang efisien saling mensubstitusi yaitu pada saluran I, II, dan III dengan nilai farmer's share berturut-turut $100 \%$, 84\%, dan 51\%. Panjang pendeknya saluran pemasaran dalam memengaruhi nilai farmer's share sangat jelas terlihat dalam penelitian ini. Saluran I merupakan petani yang langsung menjual ke konsumen, saluran II petani menjual ke pedangang pengecer (toko buah) lalu dibeli konsumen akhir, sedangkan saluran III lembaga pemasaran yang dilalui cukup panjang yaitu petani - tengkulak - pedagang besar - pedagang pengecer (pasar tradisional) - konsumen. Farmer's share yang paling rendah dalam penelitian ini terdapat pada saluran pemasaran IV, saluran ini juga memiliki banyak lembaga pemasaran yang terlibat yaitu diantaranya petani - tengkulak pedagang besar - supplier - swalayan konsumen dengan nilai farmer's share sebesar $31 \%$. Farmer's share yang tinggi dalam penelitian ini maupun dalam penelitian Nalurita (2008) disebabkan karena pendeknya saluran pemasaran maka lembaga pemasaran yang terlibat menjadi sedikit, sehingga tidak terlalu banyak lembaga pemasaran yang mengambil keuntungan (Nurhidayana et.al., 2012).

\section{KESIMPULAN DAN SARAN}

\section{KESIMPULAN}

1. Pemasaran belimbing Dewa di Kecamatan Pancoran Mas terdiri dari lima saluran pemasaran yaitu, saluran I : Petani Konsumen, saluran II : Petani - Pedagang Pengecer (toko buah) - konsumen, saluran III : Petani - Tengkulak - Pedagang Besar Pedagang Pengecer (pasar tradisional) Konsumen, saluran IV : Petani - Tengkulak - Pedagang Besar - Supplier - Pedagang Pengecer (swalayan) - Konsumen, dan saluran V : Petani - Supplier - Pedagang Pengecer (swalayan) - Konsumen.

2. Fungsi-fungsi pemasaran yang dilakukan oleh tiap lembaga pemasaran yaitu fungsi pertukaran berupa pembelian dan penjualan, fungsi fisik berupa kegiatan pengemasan, pengangkutan, dan penyimpanan, fungsi fasilitas berupa kegiatan sortasi dan grading, dan fungsi pembiayaan meliputi fungsi penanggungan resiko dan fungsi informasi pasar.

3. Farmer's share tertinggi tedapat pada saluran pemasaran pertama karena petani langsung menjual ke konsumen. Jika melewati lembaga pemasaran, saluran pemasaran kedua juga dapat dikatakan efisien karena nilai farmer's share sebesar $84 \%$. Farmer's share terendah terdapat pada saluran pemasaran keempat karena banyaknya lembaga pemsaran yang terlibat dalam saluran pemasaran ini. 
4. Berdasarkan analisis marjin pemasaran dan farmer's share menunjukkan bahwa saluran I adalah saluran pemasaran yang paling efisien. Namun, saluran II dan III dapat digunakan sebagai alternatif karena kedua saluran tersebut juga efisien.

\section{SARAN}

1. Saluran pemasaran pertama dapat dijadikan alternatif saluran pemasaran belimbing Dewa bagi petani untuk meningkatkan pendapatannya. Jika menjual semua hasil panen dirasa terlalu berat, petani dapat menerapkan strategi pemasaran campuran yaitu $70 \%$ dijual ke tengkulak dan 30\% dijual langsung ke konsumen.

2. Pemerintah kota diharapkan dapat membentuk sub-terminal agribisnis di Kecamatan Pancoran Mas sehingga petani dapat memasarkan langsung hasil panen dengan memberikan pelayanan pemasaran, meningkatkan nilai tambah dan daya saing belimbing Dewa.

3. Peneliti selanjutnya hendaknya dapat menganalisis usahatani belimbing Dewa sehingga dapat diketahui pendapatan usahatani belimbing Dewa di Kota Depok.

\section{DAFTAR PUSTAKA}

Anggraeni, S.A, Prasmatiwi, F.E., dan Situmorang, S. 2018. Analisis Pendapatan dan Pemasaran Kakao di Kecamatan Bulok Kabupaten Tanggamus. JIIA Vol 6(3): 249-256

Astriani A. 2003. Fungsi biaya dalam usaha perbenihan ikan mas: kasus Kabupaten Bandung [tesis]. Bogor: Sekolah Program Pascasarjana, Institut Pertanian Bogor.

[BPS] Badan Pusat Statistik. 2019. Kota Depok dalam Angka 2019.

[BPS] Badan Pusat Statistik. 2018. Kecamatan Pancoran Mas dalam Angka.

Din, Q.M., dan Badar, H. 2011. Marketing of Agricultural Product in Pakistan: Theory
\& Practice. Higher Education Commission (HEC). Pakistan.

Dinas Ketahanan Pangan, Pertanian, dan Perikanan Kota Depok. 2019. Data Belimbing Kota Depok 2013.

Kementerian Kesehatan Republik Indonesia. 2016. Inilah Perbedaan '4 Sehat 5 Sempurna' dengan 'Gizi Seimbang'. https://www.kemkes.go.id/pdf.php?id $=16051300001$ [ 4 Oktober 2019].

Kim, M., Curtis, K.R., dan Yeager, I. 2014. An assessment of market strategies for smallscale produce growers. International Food and Agribusiness Management Review 17: 187-204.

Nalurita, S. 2008. Analisis Efisiensi Pemasaran Belimbing Dewa di Kecamatan Pancoran Mas Kota Depok Jawa Barat. [skripsi]. Bogor: Fakultas Pertanian. Institut Pertanian

Nurhidayana., Kuswardani, R.A., \& Siregar, M.A. 2012. Analisis Efisiensi Pemasaran Cabai Merah di Kabupaten Batubara. Jurnal Agribisnis Sumatera Utara Vol 5(1): 28-39

Singarimbun, M., dan S, Effendi. 1995. Metode Penelitian Survey. LP3S. Jakarta.

Sudiyono. 2002. Pemasaran Pertanian. UMM Press. Malang.

Sugiyono. 2013. Metode Penelitian Kuantitatif, Kualitatif, dan R\&D. Alfabeta. Bandung.

Tashakkori, A., dan Creswell, J.W. 2007. Editorial: Exploring the Nature of Research Question in Mixed Methods Research. http://mmr.sagepub.com [25 Oktober 2019]

World Health Organization. 2003. Global Strategy on Diet, Physical Activity and Health.

https://www.who.int/dietphysicalactiv ity/fruit/en/ [4 Oktober 2019] 